THE REFORMATIONS IN IRELAND 
EARLY MODERN HISTORY: Society and Culture

General Editors: Rab Houston, Professor of Early Modern History, University of St Andrews, Scotland, Edward Muir, Professor of History, Northwestern University, Illinois, and Bob Scribner, Professor for the History of Western Christianity, Harvard Divinity School, Cambridge, Massachusetts

This series encompasses all aspects of early modern history from 1400 to 1800. Broadly conceived to emphasize innovative work in social and cultural history, it includes not only the traditional venues of British and European history but also the Americas and other cultures around the globe. The editors seek fresh and adventurous monographs, especially those with a comparative and theoretical approach, from both new and established scholars.

Titles include:

Samantha A. Meigs

THE REFORMATIONS IN IRELAND: Tradition and Confessionalism, $1400-1690$

Niall Ó Ciosáin

PRINT AND POPULAR CULTURE IN IRELAND, 1750-1850

\footnotetext{
Early Modern History: Society and Culture

Series Standing Order ISBN 978-0-333-71194-1

(outside North America only)

You can receive future titles in this series as they are published by placing a standing order. Please contact your bookseller or, in case of difficulty, write to us at the address below with your name and address, the title of the series and the ISBN quoted above.
}

Customer Services Department, Macmillan Distribution Ltd Houndmills, Basingstoke, Hampshire RG21 6XS, England 


\section{The Reformations in Ireland}

\section{Tradition and Confessionalism, 1400-1690}

Samantha A. Meigs

Assistant Professor of History

University of Indianapolis

Indiana, USA

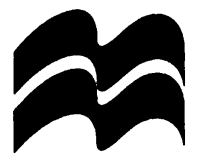


First published in Great Britain 1997 by

\section{MACMILLAN PRESS LTD}

Houndmills, Basingstoke, Hampshire RG21 6XS and London

Companies and representatives throughout the world

A catalogue record for this book is available from the British Library.

ISBN 978-1-349-25712-6 ISBN 978-1-349-25710-2 (eBook)

DOI 10.1007/978-1-349-25710-2

First published in the United States of America 1997 by

ST. MARTIN'S PRESS, INC.,

Scholarly and Reference Division,

175 Fifth Avenue, New York, N.Y. 10010

ISBN 978-0-312-17582-5

Library of Congress Cataloging-in-Publication Data

Meigs, Samantha A., 1958-

The Reformations in Ireland : tradition and confessionalism, 1400-1690 / Samantha A. Meigs.

p. $\mathbf{c m}$. - (Early modem history series)

Includes bibliographical references (p. ) and index.

ISBN 978-0-312-17582-5 (cloth)

1. Reformation-Ireland. 2. Ireland-Church history-600-1500.

3. Ireland-Church history-16th century. 4. Ireland-Church

history -17 th century. I. Title. II. Series.

BR380.M45 1997

274.15'06-dc21

() Samantha A. Meigs 1997

Softcover reprint of the hardcover 1st edition 1997

All rights reserved. No reproduction, copy or transmission of this publication may be made without written permission.

No paragraph of this publication may be reproduced, copied or transmitted save with written permission or in accordance with the provisions of the Copyright, Designs and Patents Act 1988, or under the terms of any licence permitting limited copying issued by the Copyright Licensing Agency, 90 Tottenham Court Road, London WIP 9HE.

Any person who does any unauthorised act in relation to this publication may be liable to criminal prosecution and civil claims for damages.

The author has asserted her right to be identified as the author of this work in accordance with the Copyright, Designs and Patents Act 1988.

This book is printed on paper suitable for recycling and made from fully managed and sustained forest sources.

$\begin{array}{llllllllll}10 & 9 & 8 & 7 & 6 & 5 & 4 & 3 & 2 & 1\end{array}$

$\begin{array}{llllllllll}06 & 05 & 04 & 03 & 02 & 01 & 00 & 99 & 98 & 97\end{array}$ 
In memory of my father, Charlie W. Meigs

1917-1996 


\section{Contents}

Acknowledgments $\quad$ x

Note on Usage xii

Introduction: The Irish Anomaly 1

A Note on Sources $\quad 4$

Part I: Tradition

Prologue: The Social Setting $\quad 7$

The Aes Dána $\quad 8$

$\begin{array}{ll}\text { The Chieftains } & 10\end{array}$

$\begin{array}{lr}\text { The Gaelic Monasteries } & 12\end{array}$

1 The Bardic Tradition and Gaelic Devotional Literature $\quad 16$

Cultural Implications of the Gaelic Resurgence 16

$\begin{array}{ll}\text { Gaelic Devotional Literature } & 16\end{array}$

Fifteenth-Century Bibliothèques $\quad 19$

Hagiography $\quad 21$

Gaelic Religious Poetry $\quad 22$

Sources of Bardic Religious Motifs $\quad 23$

Transmission of Religious Ideas Through Bardic Poetry 24

Religious Themes and Imagery 25

2 Bardic Influences on Gaelic Devotional Practices:

The Cult of the Saints in Late Medieval Ireland 28

Genealogies of the Saints 28

Kinship and Authority $\quad 30$

Relationships with the Saints $\quad 31$

Intercession and Protection $\quad 31$

$\begin{array}{ll}\text { Moral Coercion } & 32\end{array}$

$\begin{array}{ll}\text { Punishment } & 34\end{array}$

$\begin{array}{ll}\text { Pilgrimages, Shrines and Relics } & 37\end{array}$

3 The Pre-Reformation Institutional Church 41

$\begin{array}{ll}\text { Patronage } & 41\end{array}$

Involvement of the Laity in Religious Affairs 42

Desecration and the Violation of Sanctuary 43 
Religious Orders in Gaelic Ireland

The Church and the Two Nations

The Episcopacy in Late Medieval Ireland

Continuing Gaelic Influences in the Church

Coarbs, Erenachs and Termoners

\section{Part II: Confessionalism}

4 The Rise and Fall of Protestantism in Ireland, 1534-1603 57

The Reformation in Gaelic Ireland 58

The Gaelic Response to Protestantism $\quad 60$

Protestantism and the Old English $\quad 65$

Elizabethan Recusancy $\quad 70$

The Catholic Reformation in Ireland 73

Irish Involvement in the Council of Trent 75

5 Bards into Missionaries 77

The Bardic Tradition $\quad 78$

Gaelic Vernacular Poetry $\quad 80$

The Blending of Traditions $\quad 81$

The Evolution of Gaelic Catholic Nationalism 84

Counter-Reformation Devotional Tracts $\quad 88$

6 The Entrenchment of a Confessional Church 90

The Accession of James Stuart $\quad 90$

Episcopal Appointments $\quad 92$

Divisions Between Old Irish and Old English Clergy 93

Jurisdiction $\quad 94$

Conflict Between Regular and Secular Clergy in

Seventeenth-Century Ireland 95

The Cistercians $\quad 97$

The Friars $\quad 99$

The Jesuits $\quad 100$

Secular Clergy 102

The Evolution of an Irish Hierarchy 104

7 Elite Religion in Seventeenth-Century Ireland 108

Dissemination of Religion 109

Preaching and Oral Instruction $\quad 110$

Religious Literature in Seventeenth-Century Ireland 111

$\begin{array}{ll}\text { Sacramental Observance } & 115\end{array}$ 
Devotional Practices $\quad 119$

The Cult of the Saints 121

8 The Transformation of Traditional Religion in Ireland 123 Elite Perceptions: (1) The Anglo-Irish 'Scientists' 124

Elite Perceptions: (2) Foreign Catholics 127

Elite Perceptions: (3) The Tridentine Reformers 130

Sacramental Observance $\quad 133$

Trent I: Wakes $\quad 135$

Trent II: Charms $\quad 138$

The 'Mystification' of Gaelic Religion 139

Conclusion 141

Appendix 1: Library Lists $\quad 145$

Appendix 2: Maps 156

$\begin{array}{ll}\text { Notes } & 158\end{array}$

Selected Bibliography $\quad 198$

Index 204 


\section{Acknowledgments}

I would like to take this opportunity to thank the many people who have assisted in this research project, while noting that none are responsible for any errors or infelicities that may remain. My sincerest thanks go to the Institute of International Education for financing my research in Ireland through a Fulbright fellowship. Ireland is truly a friendly and hospitable country, and while I was there I benefitted greatly from the expertise and kind assistance of many Irish scholars. I would especially like to thank the archivists and librarians at Trinity College, Dublin; the National Library of Ireland; the Royal Irish Academy; St Patrick's College, Maynooth; and the Dublin Archdiocese. I would also like to express my gratitude to the various religious orders who kindly allowed me access to their archives - especially I would like to thank Fr Stephen Redmond, archivist of the Irish Jesuit Province and Fr Fergal Grannell and Fr Ignatius Fennessy of the Franciscan Library at Killiney for patiently answering my questions and guiding me through the rich collections of their respective orders. Other scholars in Ireland who answered questions and provided assistance include: Dr Katharine Simms, Dr Colm Lennon, Msg. Patrick Corish, Fr Peter O’Dwyer, Fr Benignus Millett, Tadhg Ó hAnnrachain, Fr Thomas Flynn, and Dr Alan Ford. Although it is dangerous to single out anyone in lists of acknowledgments I would especially like to thank Prof. Nicholas Canny, Dr Raymond Gillespie and Bernadette Cunningham for their constant support and assistance while I was in Ireland. Special thanks are also due to Prof. Máirtín Ó Murchu and the Dublin Institute for Advanced Studies for providing me with a very pleasant place to work while I was in Dublin. I also owe a special debt of gratitude to Fr Frank Fahy for a truly inspirational and informative day at Ballintober Abbey, and to Mrs Ann Rooney who indulged my interest in Irish folklore and church architecture by telling me wonderful stories and taking me to see many of the historical sites of Ireland.

I would also like to express my gratitude to several people in the US: to the Nelsons, for providing heroic technological assistance as well as general support; Lewis Johnson for indexing advice and assistance; Janice Odom for help with the proofreading; Dr Richard Wunderli for his interest, support and good advice over many years; Dr Dennis Showalter for providing assistance and encouragement at a moment when it was sorely needed; and Prof. Sarah Maza and Prof. Lacey Baldwin Smith for their encouragement and valuable suggestions at the dissertation phase. Prof. William Monter deserves extraordinary thanks for providing extraordinary assistance on this 
project. It was his suggestion that I ought to look at Irish Reformation history, and I suspect he has ended up looking at far more of it than he ever intended. Nonetheless, from the inception of the project to its completion he has provided all manner of encouragement, assistance and advice and it is with pleasure that I publicly acknowledge my gratitude. I would also like to thank the editors of this series for their valuable comments and suggestions.

Finally, I wish to record the greatest debt of all to my family - my mother Mary Colleen Meigs, my brother Mitchell Meigs, and my grandmother Sylvia Woods - who have patiently read drafts, drawn maps, checked references, and whose support and encouragement have sustained me throughout this project as well as in every other aspect of my life. My chief regret as this project draws to a close is that my father did not live to see the book in print. However, he did see many versions of the typescript and his comments and suggestions have influenced the whole project. I dedicate this book to him, with loving gratitude for a lifetime of guidance, in memory of a man who was a first-rate teacher and thinker, whose courage and determination were limitless. Without his encouragement and example I would never have tried to pursue my dreams. 


\section{Note on Usage}

There have always been a number of ways to render Gaelic names into English, and there is still no single standardized form. Rather than somewhat arbitrarily altering the spelling of names I have tried throughout to use the form preferred by the individual, both historical personages and modern historians. Where no such preference is indicated, I have simply used the most recognizable form of given names and surnames, taking into account the modern preferred usage of omitting the apostrophe in names beginning with ' $O$.' Similarly $I$ have made no attempt to modernize original spellings in primary sources, but I have tried to provide modern place-names in brackets wherever possible. On translations I have generally used the phrasing given by the editor or translator of a text, occasionally noting when a translation is inaccurate or seems ambiguous. In foreign language references in which a translator is not identified in the notes, it is to be assumed that the translations are mine. Gaelic-speakers may note that where I have used Gaelic terms in the text (for example, aes dána) I have used a simplified generic spelling to avoid confusing non-Gaelic speakers with spelling changes produced by cases, declensions, aspiration, and so forth. On these sorts of issues, no solution is ideal, but in the interest of general readership, I have chosen to sacrifice linguistic purity for what I hope is greater clarity. 